\title{
NOTE ON TEXTS, TRANSLATIONS, AND REFERENGES
}

The now-standard German edition of Nietzsche's writings is the recently completed Kritische Gesamtausgabe edited by Giorgio Colli and Mazzino Montinari (Berlin: Walter de Gruyter, 1967-1984). Zur Genealogie der Moral is to be found in part VI, volume 2 of this edition, along with Jenseits von Gut und Böse. Now that a paperback "student edition" of this edition of Nietzsche's writings is readily available, other German editions are seldom used.

The standard English translation of this work is that by Walter Kaufmann and R. J. Hollingdale, On the Genealogy of Morals, published together with Ecce Homo (New York: Vintage, 1967). Except where contributors have preferred to use their own translations of the passages they cite, or were working from translations into other languages (for example, French), this is the translation generally used in citations in this volume. (Departures are indicated in the contributors' notes.)

Kaufmann and Hollingdale have translated most of Nietzsche's completed works-in some cases together, in others one of them, in others each of them. They also have jointly translated the collection of selections from Nietzsche's notebooks published in his name under the title Der Wille zur Macht (The Will to Power). For the most part these are the translations used by contributors in their citations; again, see their notes.

Some contributors identify their citations by providing references to the Kritische Gesamtausgabe (indicating volume, notebook, and entry numbers) as well as to the specific works. The primary identification of cited passages is usually provided in the standard manner: in the body of the essays themselves, using the customary acronyms derived from the most commonly used English-language versions of their titles (see Reference Key below), followed either directly by Nietzsche's arabic section numbers (where they run consecutively through the entire work) or first by roman numerals 
indicating main parts and then by the numbers of the section within these parts. (The letter "P" is used to signify "Preface" or other such preliminary portions of the works, which Nietzsche often provided.) In most cases these numberings are supplied by Nietzsche himself, and so are the same in all editions and languages; hence their standard use for this purpose (rather than page numbers, which vary from edition to edition, or volume and page numbers in the Gesamtausgabe, which few readers possess). In some cases a bit of stretching is involved, employing roman numerals in place of "First Essay," "Second Part," and so forth; but it usually will be obvious enough what is meant.

In a few cases, however, Nietzsche uses no numbers, and so they have had to be supplied. So, for example, arabic numbers have been assigned (following Kaufmann's numbering) to the speeches or sections in each of the parts of Zarathustra to facilitate references to it; and roman numerals have been assigned to the various parts of Twilight of the Idols and Ecce Homo (as well as the Genealogy), within which his arabic numberings begin anew. This expedient is amply warranted by its transparency and convenience, in terms of economy and also of movement between editions and translations. (Many readers find it helpful to write such numberings into their copies of these texts, making it all the easier to interpret and use such references.)

A fairly extensive bibliography of studies of Nietzsche available in English may be found at the back of this volume. See also the bibliographies in my Nietzsche (London: Routledge \& Kegan Paul, 1983), Kaufmann's Nietzsche, 4th edition (Princeton: Princeton University Press, 1974), and Eric Blondel's Nietzsche, trans. Sean Hand (Stanford: Stanford University Press, 1992). 


\section{REFERENCE KEY \\ to Nietzsche's Writings}

(See Bibliography for publication information)

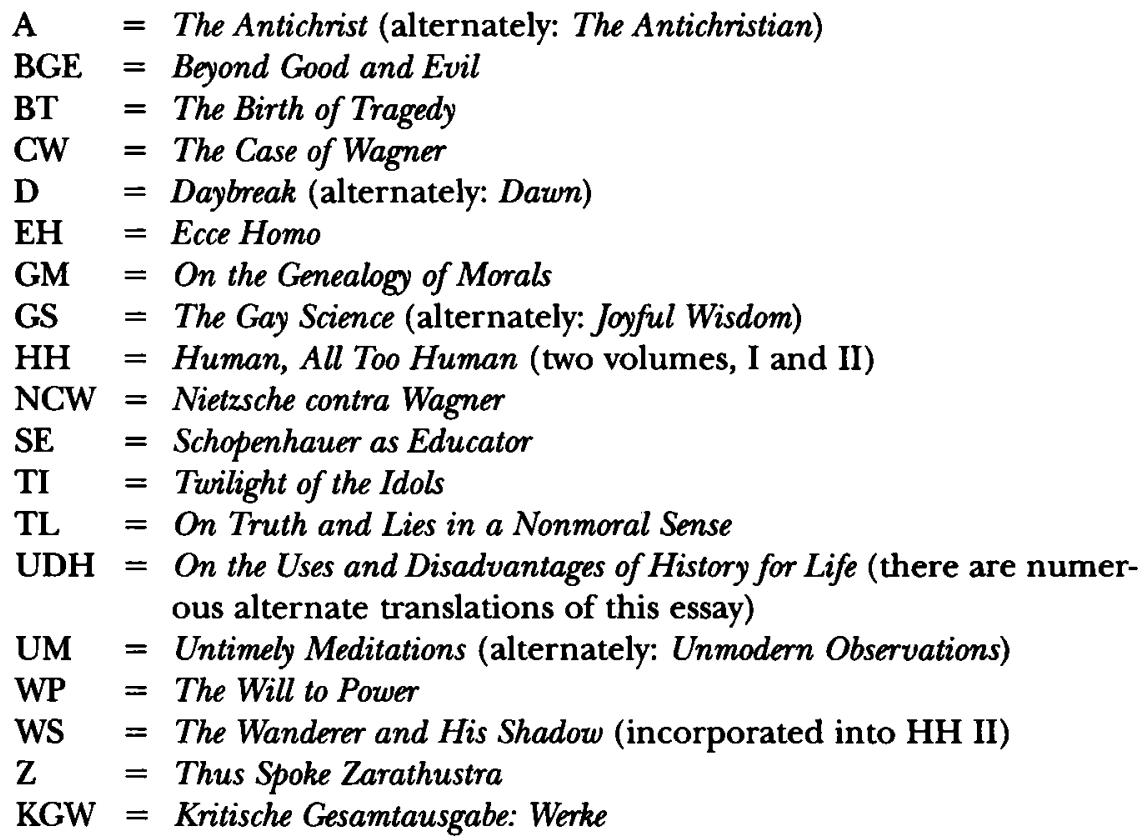


